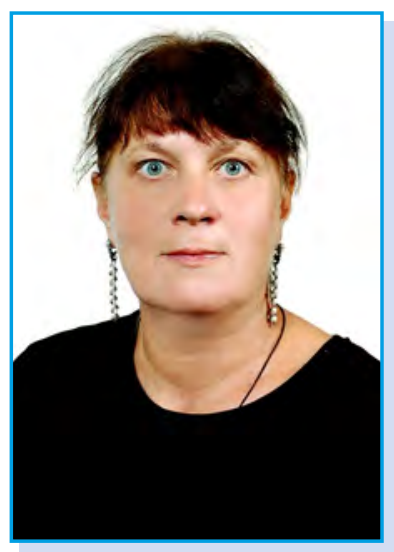

Ксенія Сізова - доктор філологічних наук, професор, завідувачка кафедри філології та видавничої справи Кременчуцького національного університету імені Михайла Остроградського, м. Кременчук, Україна.

Коло наукових інтересів: лінгвістика художнього тексту, літературознавство, методика викладання мови і літератури.

sizovax@gmail.com

https://orcid.org/0000-0002-3269-6343

кандидат педагогічних наук, доцент, доцент кафедри філології та видавничої справи Кременчуцького національного університету імені Михайла Остроградського, м. Кременчук, Україна.

Коло наукових інтересів: методика викладання української мови i літератури.

svetlana.soshenko1973@gmail

https://orcid.org/0000-0002-5634-2945

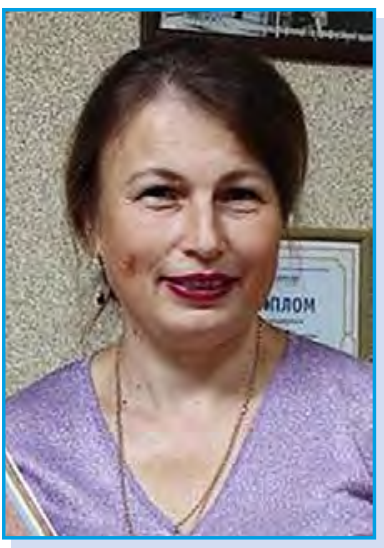

УДК 373.5.016:861

https://doi.org/10.32405/2411-1317-2021-4-214-221

\title{
ІНТЕГРОВАНІ УРОКИ УКРАЇНСЬКОÏ МОВИ ТА ЛІТЕРАТУРИ НА МАТЕРІАЛІ ТВОРУ МАРІЇ МАТІОС «СОЛОДКА ДАРУСЯ»
}

У статті розглядається дидактичний потенціал роману Марії Матіос «Солодка Даруся» для проведення серії інтегрованих уроків з української мови і літератури у старшій школі (ліцеї) філологічного профілю. Вибір для інтегрованих уроків цього художнього твору зумовлений лексико-стилістичними особливостями роману: активним використанням авторкою різноманітних лексичних одиниць (зокрема, діалектизмів), фразеологізмів та паремій для побудови художніх образів, мовної характеристики персонажів, підвищення експресивності тексту. Особлива увага приділяється формуванню в учнів ліцею предметних компетенностей, зокрема, аналізу стилістики художнього твору, ідентифікації різних лексико-фразеологічних одиниць, визначенню їх функціональних особливостей, здатності інтерпретувати літературний твір на підставі лінгвістичного аналізу.

Ключові слова: інтегрований урок; старша профільна школа; українська мова; українська література; роман Марії Матіос «Солодка Даруся»; мовна і літературна компетентності; аналіз стилістики художнього твору. 
Постановка проблеми в загальному вигляді та ії зв’язок з важливими науковими та практичними завданнями. Міжпредметна інтеграція мови і літератури у старшій школі філологічного профілю є ефективним засобом формування в учнів мовної і літературної компетентностей, зокрема, комплексного філологічного аналізу літературних творів, адже у художньому тексті зміст і форма $€$ нерозривно зв’язаними, мовні одиниці виконують важливі функції побудови образної системи твору.

Вчені наполягають на високій інформативності, фундаментальності, різноплановості інтегрованих уроків мови і літератури, їх ролі у підвищенні мотивації до навчання, зміцненні знань (Мельникова, Кібалко, Ботня, 2019). І. Кучеренко зауважує, що «успіх у навчанні української мови та літератури прямо пропорційно залежить від креативності вчителя, бажання навчити і майстерності передати свої знання учням. Досягти поставлених освітніх цілей, на нашу думку, вчительсловесник зможе за умови впровадження в практику навчання творчо підготовленої інтегрованої технології» (Кучеренко, 2018, с. 41). Осмислення досвіду проведення інтегрованих уроків, на яких учні вивчають художній текст у змістовно-формальній єдності, 3'ясовуючи ідейно-тематичну спрямованість твору шляхом аналізу мовних засобів, $є$ важливим завданням дидактики.

Вибір для інтегрованих уроків твору сучасної української жіночої прози (роману М. Матіос «Солодка Даруся») зумовлений передусім тим, що прозі письменниці притаманні новаторські мовні експерименти, сутність яких полягає у сміливому поєднанні у тексті художнього твору різноманітних лексичних одиниць, широкому вживанню фразеологізмів і паремій. Варто зазначити, що міжпредметна інтеграція мови і літератури на матеріалі новелістики М. Матіос поки що не ставала об'єктом наукових розвідок, що зумовлює актуальність цього дослідження.

Аналіз останніх досліджень і публікацій з проблеми. Творчість Марії Матіос, зокрема, роман «Солодка Даруся», є об’єктом численних філологічних студій: вчених цікавить стилістика письменниці (Бородиця, Вашків, 2019; Ісаєнко, 2012; Насмінчук, 2009; Хода, 2011), багата мовна палітра твору (Павлишин, 2011; Щетиніна, 2017). Науковці акцентують щільність, насиченість твору художніми деталями, образами-символами (Бородиця, Вашків, 2019, с. 22). Г. Павлишин наголошує, що мова $є$ найвиразнішим і найдовершенішим художнім засобом самовираження М. Матіос. На думку дослідниці, «ця мова - сама по собі витвір мистецтва, це пелюстки троякої ружі, що зачаровують красою. Авторка сплела сучасну нормовану лексику з пишним та образним мовленням буковинців. Мова повісті містить також колосальну кількість інформації, закодованої в поетичних виразах та образах» (Павлишин, 2011, с. 179).

Серед розвідок доцільно виокремити низку присвячених вживанню діалектної лексики у романі «Солодка Даруся» (Зелінська, Тищенко, 2012; Колоїз, 2010; Селіверстова, 2010; Стасик, 2013; Хомич, 2008), а також використанню фразеологічних засобів у творі (Бойко, Давиденко, 2018; Волкова, 2018; Євтушина, 2015; Ніколаєнко, 2011; Пирога, 2010; Цуркан, 2014). Як слушно зауважують О. Зелінська і Т. Тищенко, «використання діалектної лексики у художніх творах сучасності - показник культури авторського стилю. У прозових творах М. Матіос діалектні слова можуть виконувати функцію прямої номінації, набувати фігурально-образних значень, забезпечувати відповідний регіональний колорит, слугувати засобом мовної характеристики героїв» (Зелінська, Тищенко, 2012, с. 265). В. Бойко та Л. Давиденко зазначають, що М. Матіос не просто «майстерно і надзвичайно доречно використовує фразеологізми у своїх творах, але і досить часто видозмінює їхню форму, конкретизує значення усталених висловів, увиразнюючи фразеологічну семантику. Результатом цього є суттєве посилення динаміки, експресивності та національного колориту змісту твору, увиразнення авторського мовлення чи поглиблення характеристики персонажів» (Бойко, Давиденко, 2018, с. 228).

Особливо актуальними в аспекті нашого дослідження є педагогічні студії, що розкривають специфіку вивчення роману «Солодка Даруся» у школі (Привалова, 2017; Якимович, 2013). Разом 3 тим варто зазначити, що у фокусі уваги вчених є передусім ідейно-тематичне наповнення твору, його виховний потенціал, проте лексичні засоби, завдяки яким і втілюється ідейний задум письменниці, шляхи їх вивчення у школі залишаються поза увагою. 
Формулювання цілей статті. Мета статті полягає у дослідженні дидактичного потенціалу роману М. Матіос «Солодка Даруся» для проведення серії інтегрованих уроків з української мови і літератури у старшій школі (ліцеї) філологічного профілю.

Виклад основного матеріалу. Вивчення роману М. Матіос «Солодка Даруся» відбувається у межах факультативного курсу «Світ українського слова» для учнів 10-11 класів з філологічним профілем. Серія інтегрованих уроків передбачає проведення трьох занять. Перший урок спрямований на вивчення діалектної лексики у романі, другий присвячений фразеологічним одиницям, третій - використанню паремій. Така послідовність грунтується на принципі «від простого до складного», адже спочатку вивчаються слова (лексика), потім словосполучення (фразеологізми), і наприкінці - речення (прислів’я). До використаних освітніх технологій належать інтерактивні мінілекції з презентаційним супроводом, аналітичне читання художньої літератури, вивчення зразків лінгвістичного аналізу художнього тексту, виконання індивідуальних самостійних завдань. Уроки також передбачають використання науково-дослідницьких технологій: вивчення наукової літератури, структурно-семантичний аналіз. Метою інтегрованих уроків $€$ формування в учнів уявлення про взаємозв'язок і взаємозумовленість поняттєвих апаратів лінгвістики та літературознавства, призначених для вивчення художнього тексту.

Інтегрованим урокам передує самостійне ознайомлення учнів 10-х класів з романом М. Матіос «Солодка Даруся» і виконання індивідуальних завдань. До індивідуальних завдань, на виконання яких учням надається два тижні, належать пошук у тексті:

- діалектизмів на позначення елементів пейзажу;

- діалектизмів на позначення тварин і рослин;

- діалектизмів на позначення елементів одягу;

- діалектизмів на позначення речей побуту;

- діалектизмів на позначення рис людини;

- полонізмів, румунізмів;

- фразеологізмів;

- паремій.

Для виконання завдань учням рекомендується використовувати такі словниково-довідкові матеріали: «Гуцульський словник (найуживаніша лексика» (Електронне видання http:// karpaty365.com/category/228/ukr), «Короткий тлумачний словник гуцульсько-українського та руського говору (Східнокарпатський говір)» (Електронне видання https://karnauhova.at.ua/publ/11-0-3), «Фразеологічний словник української мови» (укладач В. М. Білоноженко та ін.., 1993 рік) i «Тематичний словник популярних українських прислів’їв та приказок з коментарями» (укладач В.М. Северинюк, 2018 рік). Вибір довідкових видань зумовлений тим, що вони є у відкритому доступі. Вагомим аргументом щодо користування саме цими виданнями є вдале ілюстрування лексичного матеріалу.

Запропоновані індивідуальні самостійні завдання передбачають формування вміння фахового філологічного читання художнього тексту, коли реципієнт не лише сприймає сюжет твору, але й зупиняє увагу на мовностилістичних засобах, аналізує формальне (мовне) втілення змістових концептів.

Перший урок розпочинається з презентації вчителя літератури, у якій стисло розповідається про творчий шлях М. Матіос та іїі роман «Солодка Даруся».

Далі вчитель української мови ознайомлює учнів з поняттям діалектної лексики. Потім слово надається учням, які виконували індивідуальні завдання 3 пошуку діалектизмів різних семантичних груп. Виступи відбуваються у формі презентацій - на екран виводяться фрагменти тексту, у яких трапляються діалектизми.

Наприклад, на екрані демонструється фрагмент тексту, який містить діалектизми на позначення елементів одягу: Калина два дні підряд провітрювала на обійсті джерги, коци, укривала, килими, хустки, запаски, сардаки, кептарі й усе, що могло бути видко здалеку - з гостинця, й зблизька - із лісу, начебто й не зважала на військових людей, що пленталися під ногами. ... 
а тоді мовчки, але дуже поволі, почала скидати із себе кептарик-безрукавку. Учень пояснює, що означає кожне зі слів.

Після кожного з учнівських виступів учитель літератури ставить класу запитання щодо того, яку функцію у тексті роману виконує певна семантична група діалектизмів: номінація реалій, притаманних певному регіону та добі; створення стилістичного колориту; увиразнення художнього образу. Останню функцію, наприклад, виконує у творі діалектизм трепета (осика), що символізує трагічну долю буковинців у XX столітті. Розповідаючи про роль діалектної лексики, слід пам'ятати, що художній стиль містить усі різновиди стилістичних одиниць, які відповідають творчому задуму автора.

Потім вчитель мови знайомить учнів з такими лексичними групами, як полонізми та румунізми (запозичення з польської та румунської мов відповідно). Учитель ставить класу запитання стосовно того, які екстралінгвістичні фактори вплинули на їхню велику кількість у гуцульській говірці. Після цього йде презентація індивідуального завдання, яка закінчується обговоренням функцій такої лексики у художньому тексті. Учитель літератури пропонує учням знайти запозичення з польської та румунської, які вживаються для відтворення місцевого колориту, й такі, що надають мовну характеристику персонажу.

Під час другого уроку вивчення фразеологічних одиниць розпочинається з інформації вчителя мови щодо основних різновидів фразеологізмів та їх функцій у творах літератури. Інформація грунтується на твердженні І. Волкової, згідно з яким «фразеологізми в художніх текстах $є$ невичерпним джерелом експресивності, образотворчим чинником авторської оповіді, за їх допомогою стає більш рельєфним внутрішній світ героїв, увиразнюється портретна характеристика, мова героїв твору, пейзаж, що читач сприймає більш наочно. Серед фразеологізмів виділяють загальновідомі й менш уживані. У мовленні вони виконують різні функції: оцінну, емоційноекспресивну, характеристики внутрішнього стану, портретної характеристики, мовної тощо» (Волкова, 2018, с. 24). Фразеологізми також є ефективним засобом втілення авторської позиції, віддзеркалення специфічних рис мовної індивідуальності письменниці.

Наприклад, низка фразеологізмів з оцінною функцією: На плечах голову носити, а не баняк; головою треба думати, а як думаєш ногами, то хай голова страждає; вони таки не мають смальцю в голові, а Бога в череві. В сільраді за таким розумом у книжку дивляться, а Даруся все у своїй голові тримає. Даруся голими п'ятами чує. 3 курми вона говорить краще, ніж із людьми.

Потім йде презентація індивідуальної роботи учня з виведенням на екран фрагментів тексту, в яких наявні фразеологізми. Решта учнів знаходить фразеологізми у авторській оповіді та у мові персонажів, визначає їх функції. Учитель наголошує на тому, що фразеологічні одиниці є одним 3 найважливіших способів передачі національних стереотипів, стійких історично сформованих уявлень про моральні, розумові та інші особливості, притаманні представникам певних етнічних спільнот. Фразеологізми транслюють символи і міфологеми, є частиною національної мовної картини світу. Н. Пирога, розглядаючи фразеологізми у романі «Солодка Даруся», зауважує, що «дослідження характеру і способів застосування письменницею слів у різноманітних їх сполученнях дозволяє визначити індивідуальну своєрідність творчого методу автора. Письменниця намагається зберегти всю силу, гостроту, влучність народних виразів, а заодно, рельєфно, пластично і чітко змалювати персонажів, риси їхнього життя, епоху та місце й умови подій» (Пирога, 2010, с. 393).

Аналогічний алгоритм має третій інтегрований урок, який присвячений пареміям у романі «Солодка Даруся»: стисла інформація вчителя щодо прислів’їв, презентація уривків з роману, підготовлених учнями, та обговорення функціональних особливостей прислів'їв. Прислів'я це жанр усної народної творчості та одиниці розмовної мови. Українська мова надзвичайно багата образними прислів'ями та приказками, які роблять мовлення більш виразним, самобутнім і оригінальним.

Прислів’я використовуються у літературних творах з різними функціями. Паремії у романі «Солодка Даруся» органічно вписані у контекст. Зазвичай, вони підсумовують міркування головної героїні у внутрішньому монолозі, виконують функцію узагальнення у діалогах. Детальне 
вивчення фрагментів тексту свідчить також про використання прислів'їв для характеристики персонажа, його ставлення до подій. Паремії концентрують глибину ситуації, розкривають образ героя. Можна говорити про текстотвірну роль паремій у романі «Солодка Даруся», адже часто у паремії закладена основна думка текстового фрагмента.

У результаті запропонованої серії інтегрованих уроків учні набувають систему предметних компетентностей, яка відповідає філологічному профілю навчання (див. рис. 1). До них належать:

- здатність ідентифікації лексико-фразеологічних одиниць і паремій;

- здатність комплексного аналізу твору на мовному рівні;

- вміння сприймати художній твір у єдності змісту і форми;

- вміння інтерпретувати зміст художнього твору на підставі аналізу його мовного втілення;

- вміння аналізувати суб’єктну структуру художнього тексту і встановлювати взаємозв'язки між мовними засобами, авторським задумом і стратегією.

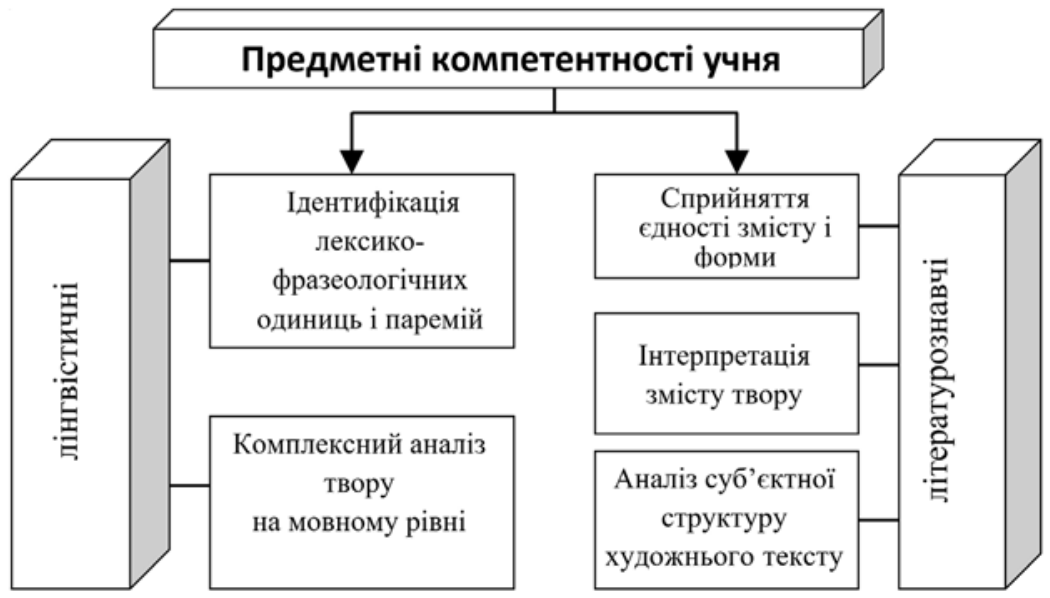

Рис. 1. Система компетентностей, що формується у результаті інтегрованих уроків з української мови та літератури

Варто зауважити, що вміння інтерпретувати художній твір крізь призму мови належить до предметних компетентностей майбутнього філолога.

На основі вивченого матеріалу можна дійти висновку про те, що М. Матіос у своєму твору наблизила українську літературну мову до гуцульської говірки, привернула увагу сучасного читача до побуту та укладу життя буковинців засобами діалектної лексики, народнопоетичної фразеології та пареміології.

Висновки та перспективи подальших досліджень. Роман М. Матіос «Солодка Даруся» має потужний дидактичний потенціал для формування предметних компетентностей учнів старшої школи філологічного профілю. Твір містить велику кількість різноманітних лексичних, фразеологічних та пареміологічних засобів, аналіз яких дозволяє усвідомлювати єдність змісту і форми художнього твору, адже саме мова $є$ втіленням ідейного задуму автора. Аналіз мовного втілення образної системи літературного твору дозволяє зрозуміти індивідуально-авторські стильові особливості, ідейно-філософський задум автора, естетичні засади творчого методу, національну своєрідність тощо. Проза М. Матіос якнайкраще відповідає завданням інтегрованих уроків, адже у ній з високою майстерністю відтворена жива мова українського народу. Письменниця продовжує традиції, закладені «Покутською трійцею», збагачуючи їх новаторськими прийомами літератури XXI століття та надбаннями української жіночої прози тощо.

Інтегровані уроки з української мови і літератури формують вміння вдумливого фахового читання, яке $є$ запорукою якісної підготовки учнів філологічного профілю навчання. Перспекти- 
ви подальших наукових досліджень вбачаємо у розробці інтегрованих уроків з української літератури та історії на матеріалі роману М. Матіос «Солодка Даруся», адже у художньому творі на прикладі людських доль розкриваються трагічні події, що відбувалися на Буковині у XX столітті. Також перспективним напрямком вважаємо розробку інтегрованих уроків з української мови та літератури, спрямованих на аналіз роману «Солодка Даруся» в аспекті наратології, оскільки твір містить широкий спектр наративних форм.

\section{Використані джерела}

[1] Кучеренко, I. А. (2018). Інтеграція у вивченні української мови та літератури в новій українській школі. Збірник наукових праць за матеріалами Всеукраїнської науково-практичної конференції «Актуальні проблеми літературної освіти (пам’яті О.Р. Мазуркевича та П.К. Волинського)». Умань: АЛМІ, 40-46.

[2] Мельникова, Р., Кібалко, Г., Ботня, I. (2019). Інтегрований урок як вид нестандартної організації навчання української літератури. Науковий вісник Ізмаїльського держсавного гуманітарного університету: збірник наукових праць. Серія «Філологічні науки». Ізмаїл: РВВ ІДГ. (44). 32-40.

[3] Бородіца, С., Вашків, Л. (2019). Особливості новелістичного мислення Марії Матіос. Філологічний дискурс. (9). 6-23.

[4] Ісаєнко, К. П. (2012). Стилістичні особливості української сучасної прози (на матеріалі творчості М. Матіос). Література та культура Полісся: Збірник наукових праць. Ніжинський держ. ун-т ім. М. Гоголя: Історико-культурні процеси Лівобережної України в загальноукраїнському контексті. (70). 15-19.

[5] Насмінчук, І. А. (2009). Стильове розмаїття прози Марії Матіос. Кам’янець-Подільський: Буйницький О.А.

[6] Хода, Г. (2011). Феномен жіночої прози в сучасній українській літературі. Вивчаємо украӥнську мову ma літературу. (2). 30-35.

[7] Павлишин, Г. Я. (2011). Багатство мовної палітри драми на три життя Марії Матіос „Солодка Даруся”. Вісник Житомирського державного університету імені Івана Франка. (58). 178-181.

[8] Щетиніна, С. (2017). Художня мова як код національної ідентичності Марії Матіос. Філологічні діалоги: Збірник наукових праць. Ізмаїл: РВВ ІДГУ. (4). 274-280.

[9] Зелінська, О., Тищенко, Т. (2012). Виражальний потенціал діалектної лексики в романах Марії Матіос. Вісник Прикарпатського університету. Філологія. (32/33). 263-268.

[10] Колоїз, Ж. В. (2010). Діалектизми в романі Марії Матіос «Солодка Даруся». Філологічні студії. Науковий вісник Криворізького державного педагогічного університету. (4). 97-116.

[11] Селіверстова, К. М. (2010). Структура діалектної лексики роману Марії Матіос «Солодка Даруся». Науковий часопис Національного педагогічного університету імені М.П. Драгоманова. Серія 10: Проблеми граматики і лексикології української мови. (6). 51-54.

[12] Стасик, М. В. (2008). «Народознавчий континуум художнього світу Марії Матіос. Вісник Запорізького національного університету. Філологічні науки. (2). 115-120.

[13] Хомич, Т. Л. (2008). Маркована лексика в ідіолекті Марії Матіос. Література та культура Полісся. (43). 94-103.

[14] Бойко, В.М., Давиденко, Л.Б. (2018). Процесуальні фразеологізми у творах Марії Матіос. Література та культура Полісся. (91). 222-230.

[15] Волкова, I. В. (2018). Фразеологія сучасного українського роману. Науковий вісник Міжнародного гуманітарного університету. Сер.: Філологія. (37, том 1). 23-25.

[16] Євтушина, Т. О. (2015). Емоційність як релевантна риса фразеологічної інтерпретації менталітету буковинців у прозі М. Матіос. Наукові праці Кам'янець-Подільського національного університету імені Івана Огієнка: Філол. Науки. (40). 80-84.

[17] Ніколаєнко, I. О. (2011). Фразеологічні засоби в романі Марії Матіос «Солодка Даруся». Актуальні проблеми слов'янської філології. Серія: Лінгвістика і літературознавство: Міжвузівський збірник наукових статей. (24, ч. 3). 404-408.

[18] Пирога, Н. Г. (2010). Фразеологічне новаторство Марії Матіос (на матеріалі роману «Солодка Даруся»). Актуальні проблеми слов'янської філології. (XXIII, ч. 3). 338-394.

[19] Цуркан, М. (2014). Загальномовна та індивідуально-авторська фразеологія у прозі Марії Матіос. Українська мова: Науково-теоретичний журнал. (4). 90-101. 
[20] Привалова, С. П. (2018). Вивчення роману Марії Матіос «Солодка Даруся». Вісник ЛНУ імені Тараса Шевченка. 3 (137). 227-234.

[21] Якимович, В. (2013). Роман Марії Матіос «Солодка Даруся» у шкільному вивченні. Актуальні проблеми гуманітарної освіти: збірник наукових праць, Кременець: ВЦ КОГПІ ім. Тараса Шевченка. 181-186.

\section{References}

[1] Kucherenko, I. A. (2018). Integraciya u vy`vchenni ukrayins`koyi movy` ta literatury`v novij ukrayins `kij shkoli. Zbirny `k naukovy`x pracz`za materialamy`Vseukrayins`koyi naukovo-prakty`chnoyi konferenciyi «Aktual`ni problemy` literaturnoyi osvity`(pam’yati O. R. Mazurkevy`cha ta P.K. Voly`ns`kogo)». Uman`: ALMI, 40-46. (in Ukrainian).

[2] Mel`ny`kova, R., Kibalko, G., Botnya, I. (2019). Integrovany`j urok yak vy`d nestandartnoyi organizaciyi navchannya ukrayins `koyi literatury`. Naukovy`j visny`k Izmayil`s`kogo derzhavnogo gumanitarnogo universy`tetu: zbirny`k naukovy`x pracz`. Seriya «Filologichni nauky`». Izmayil: RVV IDG. (44). 32-40. (in Ukrainian).

[3] Borodicza, S., Vashkiv, L. (2019). Osobly`vosti novelisty`chnogo my`slennya Mariyi Matios. Filologichny`j dy`skurs. (9). 6-23. (in Ukrainian).

[4] Isayenko, K. P. (2012). Sty`listy`chni osobly`vosti ukrayins`koyi suchasnoyi prozy` (na materiali tvorchosti M. Matios). Literatura ta kul tura Polissya: Zbirny`k naukovy`x pracz`. Nizhy`ns ky`j derzh. un-t im. M. Gogolya: Istory `ko-kul`turni procesy` Livoberezhnoyi Ukrayiny`v zagal`noukrayins`komu konteksti. (70). 15-19. (in Ukrainian).

[5] Nasminchuk, I. A. (2009). Sty 'l’ove rozmayittya prozy`Mariyi Matios. Kam’yanecz -Podil`s ky j: Bujny`cz ky`j O. A. (in Ukrainian).

[6] Xoda, G. (2011). Fenomen zhinochoyi prozy`v suchasnij ukrayins`kij literaturi. Vy`vchayemo ukrayins`ku movu ta literaturu. (2). 30-35. (in Ukrainian).

[7] Pavly`shy`n, G. Ya. (2011). Bagatstvo movnoyi palitry`dramy`na try` zhy`ttya Mariyi Matios „Solodka Darusya”. Visny `k Zhy 'tomy`rs`kogo derzhavnogo universy 'tetu imeni Ivana Franka. (58). 178-181. (in Ukrainian).

[[8] Shhety`nina, S. (2017). Xudozhnya mova yak kod nacional`noyi identy`chnosti Mariyi Matios. Filologichni dialogy`: Zbirny`k naukovy`x pracz`. Izmayil: RVV IDGU. (4). 274-280. (in Ukrainian).

[9] Zelins`ka, O., Ty`shhenko, T. (2012). Vy`razhal`ny`j potencial dialektnoyi leksy`ky`v romanax Mariyi Matios. Visny`k Pry`karpats`kogo universy`tetu. Filologiya. (32/33). 263-268. (in Ukrainian).

[10] Koloyiz, Zh. V. (2010). Dialekty`zmy`v romani Mariyi Matios «Solodka Darusya». Filologichni studiyi. Naukovy`j visny`k Kry`voriz kogo derzhavnogo pedagogichnogo universy`tetu. (4). 97-116. (in Ukrainian).

[11] Seliverstova, K. M. (2010). Struktura dialektnoyi leksy`ky`romanu Mariyi Matios «Solodka Darusya». Naukovy`j chasopy`s Nacional`nogo pedagogichnogo universy`tetu imeni M.P. Dragomanova. Seriya 10: Problemy` gramaty ky` i leksy`kologiyi ukrayins`koyi movy`. (6). 51-54. (in Ukrainian).

[12] Stasy`k, M. V. (2008). «Narodoznavchy`j konty`nuum xudozhn`ogo svitu Mariyi Matios. Visny`k Zaporiz kogo nacional`nogo universy tetu. Filologichni nauky`. (2). 115-120. (in Ukrainian).

[13] Xomy`ch, T. L. (2008). Markovana leksy`ka v idiolekti Mariyi Matios. Literatura ta kul`tura Polissya. (43). 94-103. (in Ukrainian).

[14] Bojko, V.M., Davy`denko, L.B. (2018). Procesual`ni frazeologizmy`u tvorax Mariyi Matios. Literatura ta kul tura Polissya. (91). 222-230. (in Ukrainian).

[15] Volkova, I. V. (2018). Frazeologiya suchasnogo ukrayins kkogo romanu. Naukovy`j visny `k Mizhnarodnogo gumanitarnogo universy tetu. Ser.: Filologiya. (37, tom 1). 23-25. (in Ukrainian).

[16] Yevtushy`na, T. O. (2015). Emocijnist` yak relevantna ry`sa frazeologichnoyi interpretaciyi mentalitetu bukovy`nciv u prozi M. Matios. Naukovi praci Kam’yanecz`-Podil`s`kogo nacional`nogo universy`tetu imeni Ivana Ogiyenka: Filol. Nauky`. (40). 80-84. (in Ukrainian).

[17] Nikolayenko, I. O. (2011). Frazeologichni zasoby`v romani Mariyi Matios «Solodka Darusya». Aktual`ni problemy` slov’yans `koyi filologiyi. Seriya: Lingvisty`ka i literaturoznavstvo: Mizhvuzivs`ky`j zbirny`k naukovy`x statej. (24, ch. 3). 404-408. (in Ukrainian).

[18] Py roga, N. G. (2010). Frazeologichne novatorstvo Mariyi Matios (na materiali romanu «Solodka Darusya»). Aktual`ni problemy`slov’yans`koyi filologiyi. (XXIII, ch. 3). 338-394. (in Ukrainian). 
[19] Czurkan, M. (2014). Zagal`nomovna ta indy`vidual`no-avtors`ka frazeologiya u prozi Mariyi Matios. Ukrayins ka mova: Naukovo-teorety`chny j zhurnal. (4). 90-101. (in Ukrainian).

[20] Pry`valova, S. P. (2018). Vy`vchennya romanu Mariyi Matios «Solodka Darusya». Visny`k LNU imeni Tarasa Shevchenka. 3 (137). 227-234. (in Ukrainian).

[21] Yaky`movy`ch, V. (2013). Roman Mariyi Matios «Solodka Darusya» u shkil`nomu vy`vchenni. Aktual`ni problemy`gumanitarnoyi osvity`: zbirny k naukovy`x pracz`, Kremenecz`VCz KOGPI im. Tarasa Shevchenka. 181-186. (in Ukrainian).

Ksenia Sizova, D. Sc. (Philology), Head of the Department of Philology and Publishing of Kremenchuk Mykhailo Ostrohradskyi National University, Kremenchuk, Ukraine.

Svitlana Soshenko, PhD (Pedagogy), Associate Professor of the Department of Philology and Publishing of Kremenchuk Mykhailo Ostrohradskyi National University, Kremenchuk, Ukraine.

\section{INTEGRATED LESSON ON UKRAINIAN LANGUAGE AND LITERATURE BASED ON MARIA MATIOS' NOVEL “SWEET DARUSSA"}

The paper considers the didactic potential of Maria Matios’ novel "Sweet Darussa” for conducting the integrated lessons on Ukrainian language and literature in senior profile school (lyceum) of philological profile. The choice of this novel for an integrated lesson is due to its lexical and stylistic features: the author's active use of various lexical units (in particular, dialectisms), phraseology and paremias to construct artistic images, linguistic characteristics of heroes, increase the expressiveness of the text. A series of integrated lessons involves three sessions. The first is aimed at studying dialectal vocabulary in the novel, the second one is devoted to phraseological units, the third - the use of paremias. Integrated lessons are preceded by independent studying of 10th grade students Maria Matios' novel "Sweet Darussa" and individual tasks. The proposed individual tasks involve the formation of the ability of professional philological reading of a literary text, when the recipient not only perceives the plot of the work, but also stops the attention on linguistic and stylistic means. Understanding the experience of conducting integrated lessons, in which students study the artistic text in content-formal unity, finding out the ideological and thematic orientation of the work through the analysis of language tools, is an important task of didactics. Particular attention is paid to the formation of lyceum students' competencies in the analysis of the stylistics, identification of different lexical and phraseological units, determination of their functional features, ability to interpret a literary work on the basis of linguistic analysis. As a result of the proposed integrated lessons, students acquire a system of special competencies that corresponds to the philological profile of learning. Analysis of the linguistic embodiment of the figurative system of a literary work allows to understand the individual-author's stylistic features, the ideological and philosophical idea of the author, the aesthetic principles of the creative method, national identity etc.

Keywords: integrated lesson; senior profile school; Ukrainian language; Ukrainian literature; Maria Matios’ novel “Sweet Darussa”; linguistic and literary competencies; stylistic analysis. 